\title{
Covid-19: Millions of women and children at risk as visits to essential services plummet
}

\author{
Jacqui Thornton
}

London

The coronavirus pandemic is a "magnifier of inequality" that threatens the wellbeing of women, children, and adolescents worldwide, a roundtable of influential female leaders has heard.

The United Nations has predicted that 47 million women could lose access to contraception resulting in 7 million additional unintended pregnancies over the next six months ${ }^{1}$ because of "deadly and disabling" covid-19, the virtual event was told. ${ }^{2}$

There could also be 31 million additional cases of gender based violence in low and middle income countries. Policy makers have a clear duty to protect the most vulnerable and disadvantaged and to tackle the root causes of inequality with targeted policies and resources, the participants concluded.

The high level meeting was organised by the UN's Every Woman Every Child initiative and advocacy groups Women Deliver and the Partnership for Maternal, Newborn, and Child Health. It was co-convened by Kersti Kaljulaid, president of Estonia and co-chair of the high level steering group of Every Woman Every Child, and Helen Clark, former prime minister of New Zealand and current chair of Partnership for Maternal, Newborn, and Child Health. Kaljulaid said, "The pandemic hopefully inspires us to think differently and also act quickly."

Henrietta Fore, executive director of Unicef, said that, in countries with already weak health systems, covid-19 was disrupting medical supply chains and straining financial and human resources. Visits to healthcare centres are declining owing to lockdowns, curfews, and transport disruptions, and as communities remain fearful of infection. ${ }^{3}$ She cited recent research that indicated there could be an increase in child deaths amounting to an additional 6000 a day over the next six months, and 56700 more maternal deaths. "This is a statistic we want to avoid. We are concerned about access to services," she said.

Mary-Ann Etiebet, executive director of Merck for Mothers, said that modelling showed that covid-19 would lead to additional deaths in women. In Nigeria, for example, antenatal visits were down by $50 \%$ and deliveries with a skilled birth attendant were down by $40 \%$ since the country's lockdown. In India, deliveries in health institutions have reduced by $43 \%$ since lockdown, she said.

"Women leaders at the front lines, the nurses, the community health workers, and midwives, they are telling us what's already happening. We need to ensure that essential services are still provided," Etiebet said. Merck for Mothers (https://www. merckformothers.com/2 is a 10 year initiative to design scalable solutions to help end preventable maternal deaths by drug company Merck (MSD in Europe).

The women leaders are calling for three priorities for the pandemic response. First, national policies and budgets to protect human rights and promote inclusivity, equity, and fairness-in this pandemic and its aftermath. Second, a focus on strengthening health systems, including immunisation and basic primary healthcare, to ensure universal health coverage. Third, investment in solutions that focus on partnership, with many different stakeholders working together-civil society, business, health professionals, donors, and engaged citizens, which allow women, children, and adolescents to take part in decisions that profoundly affect their health and wellbeing.

The meeting launched a social media campaign using the hashtag \#RiseForAll to show the leaders' commitment to protect and support every woman and to call on their fellow leaders and partners to do the same.

Earlier this month the World Health Organization said that progress towards the United Nations' sustainable development goals was being "thrown off track" by the covid-19 pandemic. ${ }^{5}$ Every Woman Every Child said that covid-19 was a "clarion call" for action to leave no one behind to deliver on those goals. Writing before the event, in a coauthored editorial, ${ }^{6}$ Clark, said "Covid-19 is not the great leveller, but rather the great amplifier of inequality." She said: "We must act now-while the storm is raging — or be ashamed by the number of lives swept away on our watch."

After the meeting, Every Woman Every Child is producing a detailed report with 14 actions called Immediate Steps to Safeguard Progress for Every Woman, Child and Adolescent.

United Nations Population Fund. New UNFPA projections predict calamitous impact on women's health as COVID-19 pandemic continues. 28 Apr 2020. https://www.unfpa.org/ press/new-unfpa-projections-predict-calamitous-impact-womens-health-covid-19-pandemiccontinues

2 Every Woman Every Child. Women's leadership in the covid-19 response to protect every woman and every child. https://www.youtube.com/watch?v=aqOkDuf5gw0

3 Fore HH. A wake-up call: COVID-19 and its impact on children's health and wellbeing. Lancet Glob Health 2020; 10.1016/S2214-109X(20)30238-2. 32405458

4 Unicef. As COVID-19 devastates already fragile health systems, over 6,000 additional children under five could die a day, without urgent action. https://www.unicef.org/presseleases covid-10-devastates already fragle health systems-over-6000 additiont-children

Thornton J. Covid-19 pandemic has derailed progress on sustainable development goals, says WHO. BMJ 2020;369:m1969. 10.1136/bmj.m1969 32409596

6 Kaljulaid K, Clark H, Alcocer Varela J, Machel G. Opinion: women and children will pay for this pandemic-unless we act. Thomson Reuters Foundation. https://news.trust.org/ item/20200526130612-rofbs

Published by the BMJ Publishing Group Limited. For permission to use (where not already granted under a licence) please go to http://group.bmj.com/group/rights-licensing/ permissions 
